\title{
Miranda
}

Revue pluridisciplinaire du monde anglophone /

Multidisciplinary peer-reviewed journal on the English-

speaking world

$11 \mid 2015$

Expressions of Environment in Euroamerican Culture /

Antique Bodies in Nineteenth Century British

Literature and Culture

\section{From Humanism to Nazism: Antiquity in the Work of Houston Stewart Chamberlain}

Johann Chapoutot

\section{(2) OpenEdition \\ Journals}

Electronic version

URL: https://journals.openedition.org/miranda/6680

DOI: $10.4000 /$ miranda.6680

ISSN: 2108-6559

Publisher

Université Toulouse - Jean Jaurès

Electronic reference

Johann Chapoutot, "From Humanism to Nazism: Antiquity in the Work of Houston Stewart

Chamberlain ", Miranda [Online], 11 | 2015, Online since 23 July 2015, connection on 08 September

2022. URL: http://journals.openedition.org/miranda/6680 ; DOI: https://doi.org/10.4000/miranda.6680

This text was automatically generated on 8 September 2022.

\section{cc) (i) () $\Theta$}

Creative Commons - Attribution-NonCommercial-NoDerivatives 4.0 International - CC BY-NC-ND 4.0

https://creativecommons.org/licenses/by-nc-nd/4.0/ 


\title{
From Humanism to Nazism: Antiquity in the Work of Houston Stewart Chamberlain
}

\author{
Johann Chapoutot
}

1 Houston Stewart Chamberlain was a typical member of the $19^{\text {th }}$ century British gentry but had the most atypical destiny-a destiny which was built around the culture of two countries: England which he left early and Germany which was to become his true home. The son of a naval officer-his father was an admiral in the Royal Navy -, he spent his whole youth travelling around Europe. After attending a lycée in Versailles and a boarding school in Cheltenham, he visited destination spas and various health resorts-he did not have a very sound constitution - with his chaperon and a tutor. He could have been a typical character from A Room with a View; he who could not embrace the military career his father had ambitioned for him and went on travelling instead. He spent his winters in Cannes and springs in Florence. After France, Italy, Belgium, he ended up in Vienna, then in Geneva, where he earned a Bachelor's degree in Science. He eventually settled in Dresden, Germany, after his Prussian tutor had filled his young mind with Teutonic tales of Germanic greatness. He became a member of the Wagner circle and grew quite intimate with the family of the Meister whose daughter, Eva, he ended up marrying. Houston Stewart Chamberlain, who spoke fluent German, belonged from then on to the sanctum of Germano-maniac racism, a group of worshippers who had gathered around Richard Wagner: Wagner, the bard of a reinvented Germanic mythology, who celebrated heroic figures of oneiric purity and had a slight tendency of considering that his age-the $19^{\text {th }}$ century-was leading white Germanic mankind towards decadence, degeneration and death. A true anti-Semite, Wagner wrote an essay against the perversion of the arts by the Jews entitled Jewishness in Music (Das Judentum in der Musik') that led Friedrich Nietzsche to break with him but that gained him the affection of many dubious devotees. Among them were Houston Stewart Chamberlain and many members of what historians later called the "Bayreuther Kreis", an informal circle of members and friends of the Wagner family, including Cosima Wagner, the wife of the Master, and Ludwig Schemann. Schemann, who held a doctorate in history from 
the University of Berlin, made a living as a "raciologist" (Rassenkündler) at the University of Freiburg and translated Gobineau's work in German. He also wrote numerous books on the theory of races, among which an important collection called Race and Humanities ${ }^{2}$ that earned him fame and glory in his later years, under the Third Reich. Ludwig Schemann exerted a great intellectual influence on the other members of the Wagner circle, popularizing what people started to call the "Völkisch" ideology ${ }^{3}$ : to fight against the (revolutionary) French idea of "Nation" based on the (false) assumption of equality. Counter-revolutionary theoreticians exalted in Germany the biological idea of the "Volk" and coined the word "völkisch" as an alternative to the French adjective "national". What mattered to them was biology and race, not the law or a mere artificial citizenship. It is no wonder that an Englishman like Chamberlain became part of the Wagner Circle for Britons were considered to be members of the Aryan race like any other German(ic) man. Later, the Wagner family would welcome another subject of the British Empire: Winifred Williams. She married Siegfried, Richard Wagner's only son, and was considered the only true custodian and bailiff in Bayreuth after Siegfried's death, as well as a sort of muse for Adolf Hitler, whom she greatly admired.

2 A passionate and self-educated man, Houston Stewart Chamberlain studied and read a lot, eager to explore many different fields at once: history, philosophy or the natural sciences. He defined himself as an "Ungelehrter", taking pride in not being a trained scholar, which he deemed was unworthy of his natural talents. Having learned, from a very young age, at least two foreign languages, he almost wrote better in French and in German than he did in English. After years of travelling and wandering/wondering about new ideas, he found in the racist theories of Schemann and other "Rassentheoretiker" of the time a unified vision of the world-a true "Weltanschauung". The main postulate was quite simple: everything in human history and culture could be explained by race, as Schemann would later emphasize in the three volumes of his Rasse in den Geisteswissenschaften. This idea allowed Chamberlain to combine both his vast amount of knowledge in history as well as in the humanities, in general. The self-taught student had found his philosophical stone and was ready to share his revelation ${ }^{4}$ to the public. He published in 1899, in Munich, a very large book entitled the Foundations of the 19th Century (Grundlagen des 19 Jahrhunderts). In this monumental piece of work, he tried to answer the following questions: what made (t)his period the most remarkable one in history? Why was the world precisely how it should be (the white population thus rewarded for its supremacy over the others)? What were the problems caused by modernity and how could the world be improved for the sake of the better portion - the white portion - of humanity?

3 This book has the reputation of being hard, if not impossible, to read. For today's readers, it is nothing more than a flood of words and phrases, an accumulation of commonplaces, false ideas and lies without any firm structure or real coherence. However, it was quite successful from the 1900's to the 1930's; it sold over 200000 copies. Historians must therefore make the effort to understand that, for Chamberlain's coevals, his book was important in that it provided an answer, at the time, to important questions and, to a larger extent, tried to give a meaning to history. In the 1031 pages of the two volumes, Chamberlain borrowed ideas from the leading sciences of the time (history and the natural sciences) and stood up for the dominant ideas, at the Belle Époque, of the European bourgeoisie: in other words, racism, social Darwinism and 
colonialism. His most fundamental idea was that the Germanic race was the cornerstone and the pillar of civilization. This beautiful race (in every regard) was dominant in Germany and Austria, but also within the elites of the British Empire and of the United States of America; it extended to the French elites as well, but only partly. If only those elites would come to that same awareness, they would crush any opposition and rule the world for good. More importantly, they would prevent any further decadence and avoid mixing with inferior races, like the Jews or other crossbreds.

4 Thanks to this book, and because he was someone who mattered in Bayreuth, Chamberlain later became a very important mediator in the formulation of the Nazi ideology, before he died in 1927. He was, for the Germans, the "thinker" who popularized Gobineau's ideas on the social Darwinists, providing the German bourgeoisie with a sense of its mission: "am deutschen wesen soll die welt genesen"- the German essence must heal the world. He became somewhat of a war hero during the First World War, during which he was a talented propagandist against his own country, Great Britain. An early "Lord Haw-Haw" of sorts who was even awarded the iron cross by Kaiser William II, not for fighting in the muddy trenches of the Somme, but for insulting London in vindictive articles. In the 1920's, he met Hitler. He then joined the Nazi party before he passed away in 1927. Since the purpose of his Foundations of the $19^{\text {th }}$ Century was to try and explain everything about life and history, it naturally had to start with Antiquity for the author's exhaustive survey to have any semblance of logic at all. Chamberlain devotes some 500 pages-nearly half the book-to that period, providing his reader with ample material on Rome, Greece and the Jews as well as on another sacrosanct trinity: Athens, Rome and Jerusalem. Those three cities had been, throughout the $19^{\text {th }}$ century, the epitome of Western culture: the Greeks had bequeathed philosophy and the arts, the Romans the Law and the Empire, and Jerusalem had opened a new path to salvation with the teachings of Jesus Christ. Chamberlain chose to revisit this holy triangle through the "völkisch" perspective.

5 Athens represented, for Chamberlain, the beauty of ideas and the greatness of philosophy, which as such is not a very original idea. In his book, we can read that Plato was, by all means, a great philosopher. As for Aristotle, he would not have been remembered in the same way had it not been for Plato. Athens was beautiful, but Greece was splendid: the people looked like statues, they had perfectly proportioned noses and marble skin, they spoke the language of books (written in Greek) and they invented not only mathematics but also the theatre and the art of warfare. This meant rewriting, mimicking and sometimes even plagiarizing parts of Hegel's Lectures on the Philosophy of History, which, since it had been posthumously published in 1837, had become mandatory homework for those who wanted an easy introduction to the work of the great philosopher. Like Hegel, Chamberlain praised the Greeks for inventing freedom and the key notion of personality: "Over there, in Asia, in the East, no man had ever been a person. Here, in Greece, every river, every stone lives and is an individual. Silent nature awakes to the consciousness of itself6". Still, the Greeks were far from perfect. Chamberlain criticized them for their lack of political sense: "The Greeks have always been, and are still today, unfaithful, unpatriotic, self-centred ${ }^{7 "}$. They were never able to create a unified Hellenic state and, instead, spent centuries launching fratricide wars against each other, only to exhaust the race in endless massacres of the Athenians by the Spartans and vice versa, until it bled to death. This is one of the better clichés of 
the German historiography of the second half of the $19^{\text {th }}$ century: only the Nordic king, Alexander of Macedonia, managed to unify Greece and put an end to endless campaigns by creating an Empire, like King Wilhelm of Prussia who succeeded in 1871 in unifying the different German tribes and states into a mighty Empire. ${ }^{8}$ Fortunately, the Greeks were great artists, like the Germans themselves. This idea according to which the Greeks and the Germans shared the same taste for beauty had been a commonplace for Konversationslexika since Johann Winckelmann published, in 1764, his Geschichte der Kunst des Altertums (History of Ancient Art). ${ }^{9}$ In the words of Chamberlain: "This assumption of the importance of the arts corresponds to a specific character of the German mind, if I am not mistaken ${ }^{10 "}$.

But what was to be said about Rome? If Greece had fathered the spirit, Rome had mastered the organisation. While the Greeks rejoiced in the company of ideas, the Romans were materialists in both the best and the worst sense of the term. If the Greeks were philosophers, the Romans were lawyers. While the Greeks had given Europe a soul, the Romans were busy shaping the body: the Imperium, the jus romanum, the legions. Chamberlain indulges in the most appalling stereotypes of the Bildung of his time. Before praising the Romans for being good lawyers, he blames them for their lack of creativity:

Can you find one single poetic genius among the Romans? (...). What can you say of a 1200 years long history that does not offer a single philosopher, not even the most modest one? (...) Where are the roman scientists? Please, do not mention this painstaking compiler, good enough to write mediocre encyclopaedias named Plinius ${ }^{11 "}$.

Chamberlain has nothing but contempt for Plinius, who might have been less of a "mediocre" Konversationslexikonsredakteur, as he puts it, than he was himself. Chamberlain compiles here a collection of the most trivial commonplaces which anyone could have easily uttered, if only to appear literate at the table of a Kommerzrat in Germany or of a first baronet in England. Chamberlain could very well have been a poor man's Hegel: rewriting the history of civilization in a less than talented way, apologizing for not being able to elaborate further on what he was talking about because it would take too long and writing much nonsense on the science of the time which he was already busy repudiating.

What is interesting, however, is the following statement: according to Chamberlain, the Romans and the Greeks, the founding fathers of our European civilization, were indeed Germans. The Germanic giants from the forests of the north were "blood from their blood and spirit from their spirit ${ }^{12}$ " and, as such, "the true heir of the Romans and of the Greeks ${ }^{13}$ ". In very ancient times, Germanic tribes had come from the north to colonize the south. They settled down in Greece and Rome, enjoying the benefits of cultural photosynthesis, thanks to the sun and mild climate of the Mediterranean. While their cousins who had stayed in the north still ate raw meat and lived in caverns, the Germans of the South - that is to say, the Greeks and the Romans-ate healthy food and created civilisation. They then left testimonies of their genius in immaculate and pristine temples that were currently used, in the $19^{\text {th }}$ century, to demonstrate the superiority of white mankind. This idea was borrowed by Chamberlain from many racist historians and theoreticians of the time. To prove the excellence of Germanic blood, scientists and race specialists had argued, since the 1830's, that every light came from the North, and not from the East. This is summed up by Chamberlain who, 
contrary to Hegel who wrote "Ex oriente lux", pretends that "Ex septentrione lux": the beacon of civilization lies in the north with the white Germanic race.

During ancient times, the "Germans" ruled over their conception of the world and could therefore explore and organize it: the science of the Greeks helped understand the cosmos, while the legions and the laws of the Romans imposed the Nordic order to the world. The known world, the oekoumene, reached its apex around the first century A.D., when the Romans, having conquered Greece, managed to combine their chtonian gravitas with the celestial intelligence and inspiration of the Greeks. Nearly as significant and important was the fact that, thanks to the Roman conquest, the Greeks finally turned their back to the East, in other words to Asia:

Without Rome, undoubtedly, Europe would have been a mere perpetuation of the Asian chaos. Greece has always gravitated around Asia, till Rome dragged it away, to the West. We have to thank Rome (...) that it transferred the centre of gravity of civilization to the West and that the Jewish-Asian spell was broken, so that Germanic Europe became the beating heart and the thinking brain of whole mankind. ${ }^{14}$

Apart from being a compendium of all the cultural clichés of the time, Chamberlain's Foundations is a form of prolonged indictment against the Jews, depicted as a race full of hatred, longing for might and vengeance. As they wanted to destroy anything that was not Jewish, they fought against the Greeks. The Persians indeed were Jews, at least as much as the Greeks were Germans, and the Persian Wars were nothing else than a racial struggle which lasted over a century between Asia and Europe. They then engaged with the Romans: Carthage was a Jewish kingdom and Hannibal himself was some sort of a fighting rabbi! Thanks to the Romans, the legions saved mankind from this plague:

People have not stopped complaining about the destruction of Carthage, from Polybius to Mommsen! But something is as clear as the sun at midday: if the Phenician people had not been exterminated (...) mankind would never have experienced (...) this $19^{\text {th }}$ century that we can consider with pride and hope ${ }^{15 "}$.

11 For Chamberlain, the victory of the Carthaginians over the Romans would have been a catastrophe: "We have been saved by the brutal delenda est Carthago" of Cato and the likes. The "Jews" of Semitic Carthage were defeated because the Romans (or Germans) were the best at fighting and winning. Later, when the Jews rebelled in Palestine, under Vespasian and Titus, and then under Hadrian, they were beaten once again: "There is a second roman delenda of overwhelming significance for world history: the delenda est Hierosolyma". Jerusalem is to be destroyed: an imperative the Romans followed at least twice, to crush the rebellions of "those Jews who spend their time revolting against every state order" because their race was synonymous with chaos.

In the end, Rome triumphed. But it also disappeared. What is left of Rome today is no other than a landscape of ruins which looks like the white skeleton of a dead civilization. What then could possibly have happened? The Romans, of course, were the best, but they did not protect themselves; they did not protect the excellence of their blood. This "race of heroes" which "carried out a Herculean task" by creating the Imperium was defeated by hybrid weaklings from "Asia minor, Greeks and Jews" who infiltrated the Empire and the most inner circles of imperial power, thus becoming the juridicial "counsellors" of the throne. By way of mixture and integration, the Romans changed and gave birth to a breed of mongrels, giving out the Roman citizenship (civitas romana) to every free man on earth. The edict of Caracalla in 212 was the 
beginning of the end: the Romans were to die of a slow death, all victims of this blood disease, after having mixed their blood with Arabs, Africans and Jews. Chamberlain scorned this "racial chaos of the late Roman Empire, which destroyed any racial and national principle ${ }^{16 "}$ "this "chaos of peoples of the decadent Roman Empire" being a capital "sin against nature ${ }^{17 "}$.

13 As a true Wagnerian, Chamberlain needed heroes and saviours. Despite this biological disaster or the inevitable fall of the Romans, the Nordic race did not disappear. The Europe the Romans had ambitioned was saved by a racial messiah: the Germanic tribes which, by invading the Empire, preserved the continent and its civilization. The Teutonic warrior is therefore celebrated by Chamberlain's book with the same resonating fury as Wagner's operas:

Without him, the Indo-Europeans would have disappeared. In a criminal way, the Asian and African slave had crawled up to the throne of the Roman Empire. The Syrian bastard had taken possession of laws, and the Jew used the Library of Alexandria to adapt Greek philosophy to the Mosaic Law (...). It was high time the saviour appeared. ${ }^{18}$

Contrary to what is being taught by "those who are too lazy to think and by flagrant historical lies", the Germanic invasions did not destroy the Empire but saved it from its fatal "jewification" and degeneration.

The second Saviour (with a capital S) is Jesus Christ himself whom Chamberlain celebrates at length in his book. Christianity is, for the author, a pillar of European culture. No surprise there, because, according to him, Christ was also a German. Not a Jew, by all means! Jesus Christ was, strangely enough, of pure Germanic blood. Chamberlain is not the first eccentric who is championing this very bizarre cause-perhaps bizarre only to us. For many people in the $19^{\text {th }}$ century, it was a vital question ${ }^{19}$ : many Christian racists of the period could not bear the idea of their Messiah being a Jew. So they "Aryanised" him. And Chamberlain would not be the last to perform such a tour de force. It would be the official creed of the Deutsche Christen under the Third Reich; for instance, an official Protestant church pledged to the Nazi party ${ }^{20}$. It was not really a success, mainly because Hitler did not agree with Chamberlain's glorification of Christian culture; but also because he believed that Christ was a mixedblood; he who was born, according to the Führer, from a Roman soldier and a Palestinian prostitute named Mary ${ }^{21}$ : "You cannot make an Aryan out of Jesus that is nonsense. What Chamberlain wrote in his Foundations is just stupid, to put it nicely" ${ }^{22 "}$ Hitler saw in Christianity a lethal plague that had affected Europe because of the Jews who made Christians out of Germans to weaken them. He resented Chamberlain for not being aware of that scourge. In that respect, he is not being entirely fair to the author. If you read the book carefully, the notion of plague as a potential threat is omnipresent. In Chamberlain's work, the past is a warning for the present. If Germanic blood is not protected against the Jewish infection, Europe will perish. This obsession with diseases and the assimilation of blood-mixing with infection is a common characteristic, as well as a deep concern, among the most convinced racists of the time, ${ }^{23}$ and not just in Germany. The immigration of strangers to the race was recurrently presented as the invasion of microbes and viruses into a healthy and sound body.

16 After the shock of the First World War and of Germany's defeat, Chamberlain slowly faded away. He became ill but was reinvigorated by a visit Adolf Hitler paid him in 1923. Hitler wanted the support of someone whose work had become a canonical book for the racist nationalists in Germany. Furthermore, his belonging to the Wagner family was a 
letter of credit and a sign of distinction in the small but growing world of the far right movements. Chamberlain saw in Hitler the new William II who could save Germany, as he wrote to him in a moving letter in the form of an accolade from the old philosopher of the race to the young racist politician. ${ }^{24}$ Chamberlain addresses a "most respected and dear Herr Hitler", the only one who could give him strength and peace, confidence and energy, everything that he had lost in August 1914, when Germany entered a fateful war:

I have been wondering why it was you of all people, you who are so extraordinary in awakening people from sleep and humdrum routines, who recently gave me a longer and more refreshing sleep than I have experienced since that fateful day in August 1914 when I was first struck down by this insidious sickness. Now I believe I understand that it is precisely this that characterizes and defines your being: the true awakener is at the same time the bestower of peace ${ }^{25}$.

Indeed, this encounter and interview left such an impression on Chamberlain that he considered Hitler as the epitome of many essential virtues-such virtues as warmth, kindness and selflessness, all embodied by the Führer of the NSDAP:

You are not at all, as you have been described to me, a fanatic. In fact, I would call you the complete opposite of a fanatic. The fanatic inflames the mind, you warm the heart. The fanatic wants to overwhelm people with words, you wish to convince, only to convince them-and that is why you are successful. Indeed, I would also describe you as the opposite of a politician, in the commonly accepted sense of the word, for the essence of all politics is membership of a party, whereas with you all parties disappear, consumed by the heat of your love for the fatherland. ${ }^{26}$

Resorting to antique concepts and quoting Goethe, Chamberlain celebrates Hitler as the creator of a cosmos, the hero who fights against every sort of chaos: "You know Goethe's distinction between force and force. There is the force that stems from chaos and in turn leads to chaos, and there is the force which shapes the cosmos ${ }^{27 "}$.

Although he did not agree with everything he had written in the Foundations, Hitler knew how to value such honour. He reciprocated by paying a tribute to Chamberlain in Mein Kampf. If politicians had been more aware of his work, states would be far better off now, writes Hitler: "Those who had the government of the country in their hands were quite as indifferent to principles of civil wisdom laid down by thinkers like H. S. Chamberlain as our political leaders now are. These people are too stupid to think for themselves ${ }^{28}$ ". Reassured though he was to have met the saviour of Germany and of the German race, Chamberlain did not die right away and had to wait four more years before falling into a deep and peaceful "sleep". Hitler and Goebbels got the chance to pay him another visit, in May 1926, just before he passed away. This second visit was, according to Goebbels, a heartbreaking episode which Berlin's new Gauleiter described in his diary, in May 1926:

Shattering scene: Chamberlain on a couch. Broken, mumbling, tears in his eyes. He holds my hand and won't let me go. His big eyes burn like fire. Greetings to you, spiritual father. Trailblazer, pioneer! I am deeply upset. Off we go. He mumbles, wants to speak, he can't-and then weeps like a child! Long, long handshake! Farewell! You stand by us when we are near despair. Outside the rain patters! I want to cry out, I want to weep. ${ }^{29}$

Houston Stewart Chamberlain died far too early to witness the rise of the NSDAP and the Gleichschaltung of Germany under Nazi rule. Being a Nazi in 1926 was just not the same than being a Nazi in 1938, 1942 or 1944. The early Parteigenossen of the 1920's or 
the people who cast their ballot for the NSDAP in the 1930's did not want the annihilation of Poland or the Holocaust. But in his book, Chamberlain laid down the foundations for a vision of history that was to nurture the Nazi Weltanschauung. As a tribute to Chamberlain, and in the similar style of his book, Alfred Rosenberg, the chief ideologist of the Nazi party, entitled his own work, The Myth of the 20th Century-a book which was meant to be, with Mein Kampf, the gospel of Nazism. This attempt at completing the Nazi evangelium was not crowned with success: Hitler, who considered Mein Kampf as sufficiently self-explanatory, despised Rosenberg's reflections which Goering himself went as far as to call a mere "philosophical burp".

From the Foundations of the $19^{\text {th }}$ to the Myth of the $20^{\text {th }}$ Century, the vision of antiquity remained the same: a Germanic golden age in Greece and Rome which was scattered and shattered by the Jews. This would be taught in the ideological courses every member of the party (among which, members of the SS) had to take. Rome was destroyed by the Jews because it had not protected the purity of its race and because it was never able to lead a proper racial war: a total war of annihilation. Delenda est Carthago, but this time for good-a word to the wise for people who were sent fighting the new Carthage of Jewish bolshevism on the Eastern front.

\section{BIBLIOGRAPHY}

Bergen, Doris L., Twisted Cross. The German Christian Movement in the Third Reich. Chapel Hill, University of North Carolina Press, 1996.

Chamberlain, Houston Stewart, Die Grundlagen des neunzehnten Jahrhunderts, 2 vols, Munich, Bruckmann, 1899.

Decultot, Elisabeth, Johann Joachim Winckelmann. Enquête sur la genèse de l'histoire de l'art, Paris, PUF, Perspectives Germaniques, 2000.

Fenske, Wolfgang, Wie Jesus zum „Arier“ wurde. Auswirkungen der Entjudaisierung Christi im 19. und zu Beginn des 20. Jahrhunderts, Darmstadt, Wissenschaftliche Buchgesellschaft, 2005.

Field, Geoffrey G., Evangelist of Race. The Germanic Vision of Houston Stewart Chamberlain, New York, Columbia University Press, 1981.

Goebbels, Joseph, Das Tagebuch von Joseph Goebbels, 1925-1926, Stuttgart, Deutsche Verlags-Anstalt, 1960.

-, The Early Goebbels Diaries, 1925-1926, London, Weidenfeld and Nicholson, 1962.

Hitler, Adolf, Mein Kampf, Munich, Franz Eher Verlag, Zentralverlag der NSDAP, 1926.

Rauschning, Hermann, Gespräche mit Hitler, Wien, Zürich, New York, Europa Verlag, 1940.

Schemann, Ludwig, Die Rasse in den Geisteswissenschaften-Band II: Hauptepochen und Hauptvölker der Geschichte in ihrer Stellung zur Rasse, Munich, Lehmanns Verlag, 1930.

Stackelberg, Roderick, Winkle, Sally, The Nazi Germany Sourcebook. An Anthology of Texts, London, Routledge, 2002. 
Wagner, Richard, Das Judentum in der Musik, Leipzig, 1869.

Weindling, Paul, Epidemics and Genocide in Eastern Europe, 1890-1945, Oxford, Oxford University Press, 2003.

-, Health, Race and German Politics between National Unification and Nazism, 1870-1945, Cambridge, Cambridge University Press, 1989.

\section{NOTES}

1. Wagner, Richard, Das Judentum in der Musik, Leipzig, 1869. This book had already been published in 1850, but anonymously. Only 1869 did Richard Wagner authorize its publication under his name.

2. Schemann, Ludwig, Die Rasse in den Geisteswissenschaften-Band II: Hauptepochen und Hauptvölker der Geschichte in ihrer Stellung zur Rasse, Munich, Lehmanns Verlag, 1930, 419 p.

3. Puschner, Uwe, Die völkische Bewegung im wilhelminischen Kaiserreich. Sprache-Rasse-Religion, Darmstadt, WBG, 2001, 464 p.

4. Field, Geoffrey G., Evangelist of Race. The Germanic Vision of Houston Stewart Chamberlain, New York, Columbia University Press, 1981, 565 p.

5. Chamberlain, Houston Stewart, Die Grundlagen des neunzehnten Jahrhunderts, Munich, Bruckmann, 1899, 1031 p. (2 volumes).

6. «Drüben, im asiatischen Osten, hatten und haben nicht einmal die Menschen Persönlichkeit, hier, in Hellas, ist jeder Fluss, jeder Stein belebt, individualisiert, die stumme Natur erwacht zum Bewusstsein ihrer selbst“, in Chamberlain, Houston Stewart, Die Grundlagen des neunzehnten Jahrhunderts, op. cit., p. 50.

7. « Der Grieche war von jeher, was er noch heute ist, untreu, unpatriotisch, eigensüchtig“, Ibid., p. 50 .

8. Demandt, Alexander, „Politische Aspekte im Alexanderbild der Neuzeit. Ein Beitrag zur historischen Methodenkritik“, in Archiv für Kulturgeschichte, 64, 1972, pp. 325-363. Christ, Karl, Hellas: Griechische Geschichte und deutsche Geisteswissenschaft, München, C.H. Beck, 1999, 534 p. NÄF, Beat, Von Perikles zu Hitler ? Die athenische Demokratie und die deutsche Althistorie bis 1945, Peter Lang, Bern, New York, 1986, 332 p.

9. Decultot, Elisabeth, Johann Joachim Winckelmann. Enquête sur la genèse de l'histoire de l'art, Paris, PUF, Perspectives Germaniques, 2000.

10. «Diese Anschauung von der Bedeutung der Kunst entspricht auch, wenn ich nicht irre, einer spezifischen Anlage des deutschen Geistes“.

11. «Gibt es unter den Römern ein einziges wahres Dichtergenie? (...). Was sagt man zu einer Geschichte, die mehr als 1200 Jahre umfasst, und nicht einen einzigen Philosophen aufweist, ja, nicht einmal das kleinste Philosöphchen? (...). Wo ist ein grosser, schöpferischer Naturforscher unter den Römern ? Doch nicht etwa der fleissige Konversationslexikonsredakteuyr Plinius ?", in Chamberlain, op. cit., pp. 77-78.

12. «Blut von ihrem Blut und Geist von ihrem Geist", ibid., p. 549.

13. « der rechtsmässige Erbe des Hellenen und des Römers“, ibid.

14. «Ohne Rom, das ist sicher, wäre Europa eine blosse Fortsetzung des asiatischen Chaos geblieben. Griechenland hat stets nach Asien gravitiert, bis Rom es losriss. Dass der Schwerpunkt der Kultur endgültig nach Westen verlegt, dass der semitisch-asiatische Bann gebrochen (...), dass das vorwiegend indogermanische Europa nunmehr das schlagende Herz und das sinnende Hirn der ganzen Menschheit wurde, das ist das Werk Roms“, Ibid., p. 168.

15. «Wie viel hat man nicht über die Vertilgung Karthagos durch die Römer gewehklagt und moralisiert, von Polybius bis zu Mommsen! (...). Eines ist aber so klar wie die Sonne am Mittag : 
wäre das phönezinische Volk nicht ausgerottet (...), so hätte die Menschheit dieses 19. Jahrhundert, auf welches wir jetzt (...) mit Stolz und zu Hoffnungen berechtigt zurückblicken, niemals erlebt", Ibid., p. 161.

16. « Das Rassen- und Nationalitätlose Völkerchaos des spätrömischen Imperiums“, Ibid., p. 371.

17. « eine Versündigung gegen die Natur", Ibid.

18. «Ohne ihn ging der Tag des Indoeuropäers zu Ende. Meuchelmörderisch hatte sich der asiatische und afrikanische Knecht bis zum Thron des römischen Imperiums hinaufgeschlichen, inzwischen der syrische Bastard sich des Gesetzeswerkes bemächtigte, der Jude die Bibliothek zu Alexandria benutzte, um hellenische Philosophie dem mosaischen Gesetze anzupassen (...). Es war hohe Zeit, dass der Retter erschien“, Ibid., p. 549.

19. Fenske, Wolfgang, Wie Jesus zum „Arier“ wurde. Auswirkungen der Entjudaisierung Christi im 19. und zu Beginn des 20. Jahrhunderts, Darmstadt, Wissenschaftliche Buchgesellschaft, 2005

20. Bergen, Doris L., Twisted Cross. The German Christian Movement in the Third Reich. Chapel Hill, University of North Carolina Press, 1996.

21. Hitler, Adolf, private talk from Oct. 21st, 1941, Führerhauptquartier, quoted in Hitler, Adolf, Monologe im Führerhauptquartier, 1941-1944. Die Aufzechnungen Heinrich Heims, herausgegeben von Werner Jochmann, Hamburg, Albrecht Knaus Verlag, 1980, 496 p., p. 96.

22. «Den Jesus können Sie nicht zum Arier machen, das ist Unsinn. Was der Chamberlain da in seinen Grundlagen geschrieben hat, ist gelinde gesagt dumm ", Hitler quoted in Rauschning, Hermann, Gespräche mit Hitler, Wien, Zürich, New York, Europa Verlag, 1940, p. 51.

23. Weindling, Paul, Epidemics and Genocide in Eastern Europe, 1890-1945, Oxford, Oxford University Press, 2003, 463 p. And Weindling, Paul, Health, Race and German Politics between National Unification and Nazism, 1870-1945, Cambridge, Cambridge University Press, 1989.

24. Chamberlain, Houston Stewart, "Sehr geehrter und lieber Herr Hitler... 7. Oktober 1923 ", quoted in Stackelberg, Roderick, Winkle, Sally, The Nazi Germany Sourcebook. An Anthology of Texts, London, Routledge, 2002, $496 \mathrm{p}$.

25. «Es hat meine Gedanken beschäftigt, wieso gerade Sie, der Sie in so seltenem Grade ein Erwecker der Seelen aus Schlaf und Schlendrian sind, mir einen so langen erquickenden Schlaf neulich schenkten, wie ich einen ähnlichen nicht erlebt habe seit dem verhängnisvollen Augusttag 1914, wo das tückische Leiden mich befiel. Jetzt glaube ich einzusehen, daß dies grade Ihr Wesen bezeichnet und sozusagen umschließt: der wahre Erwecker ist zugleich Spender der Ruhe».

26. « Sie sind ja gar nicht, wie Sie mir geschildert worden sind, ein Fanatiker, vielmehr möchte ich Sie als den unmittelbaren Gegensatz eines Fanatikers bezeichnen. Der Fanatiker erhitzt die Köpfe, Sie erwärmen die Herzen. Der Fanatiker will überreden, Sie wollen überzeugen, nur überzeugen, - und darum gelingt es Ihnen auch; ja, ich möchte Sie ebenfalls für das Gegenteil eines Politikers - dieses Wort im landläufigen Sinne aufgefaßt - erklären, denn die Asche aller Politik ist die Parteiangehörigkeit, während bei Ihnen alle Parteien verschwinden, aufgezehrt von der Glut der Vaterlandsliebe ».

27. «Sie haben Gewaltiges zu leisten vor sich, aber trotz Ihrer Willenskraft halte ich Sie nicht für einen Gewaltmenschen. Sie kennen Goethes Unterscheidung von Gewalt und Gewalt! Es gibt eine Gewalt, die aus Chaos stammt und zu Chaos hinführt, und es gibt eine Gewalt, deren Wesen es ist, Kosmos zu gestalten ».

28. Hitler, Adolf, Mein Kampf, Munich, Franz Eher Verlag, Zentralverlag der NSDAP, 1926, 782 p. Quote from vol. I, chap. 10, p. 296, in the English translation by MURPHY, James, London, Hurst and Blackett, 1939, vol. I, chap. 10, p. 153.

29. Goebbels, Joseph, Das Tagebuch von Joseph Goebbels, 1925-1926, Stuttgart, Deutsche VerlagsAnstalt, 1960, 141 p., in the English translation: The Early Goebbels Diaries, 1925-1926, London, Weidenfeld and Nicholson, 1962, 156 p., p. 77. 


\section{ABSTRACTS}

Houston Stewart Chamberlain was a social Darwinist and a true racist. He also had quite a vast cultural knowledge for a self-made man. Both an art lover and a dilettante, he was welcomed into Richard Wagner's larger circles when he became his son-in-law. In 1899, his Foundations of the 19th Century allowed him to reach public fame. In it, he provides his readership with a new approach to Western history in relation to the question of race and the necessary rise of Germanic power. Greek and Roman antiquity play an essential part in his argumentation. He was therefore read and admired by the major figures of the Nazi ideology-one of whom was Hitler-and became, just before he died, in the 1920's, one of the leading minds of their movement.

Darwiniste social et raciste convaincu, Houston Stewart Chamberlain s'est constitué une vaste culture d'autodidacte. Encyclopédiste et dilettante à la fois, amateur d'art, il a pénétré le cercle des wagnériens et est devenu le gendre de Richard Wagner. En 1899, ses Fondements du $19^{\text {ème }}$ siècle le font connaître d'un vaste public : il y relit la totalité de l'histoire de l'occident au prisme de la race et du nécessaire avènement de la puissance germanique. Dans sa démonstration, l'antiquité gréco-romaine tient une place essentielle. Lu et admiré par les principaux idéologues nazis, dont Hitler, il devient, peu avant sa mort dans les années 1920, un des maîtres à penser de leur mouvement.

\section{INDEX}

Mots-clés: racisme, völkisch, humanités, darwinisme social, national-socialisme

Keywords: racism, völkisch, humanities, social Darwinism, national-socialism

\section{AUTHORS}

\section{JOHANN CHAPOUTOT}

Professor of History - Junior Member, Institut Universitaire de France

Sorbonne Nouvelle University

johann.chapoutot@univ-paris3.fr 